\title{
Victims of trafficking and modern slavery or agents of change? Migrants, brokers, and the state in Ghana and Myanmar
}

\section{PRIYA DESHINGKAR, MARIAMA AWUMBILA and JOSEPH KOFI TEYE}

Abstract: The authors provide critical insights into the creation of unfree labour in Ghana and Myanmar by examining the roles of brokers, the state, and employers in positioning migrants in exploitative work in Libya, the Middle East, Singapore, and Thailand. The analysis draws on in-depth interviews with migrant construction workers and domestic workers, formal and informal brokers, transport providers, and other stakeholders. The authors show that brokerage is embedded in systems of reciprocity and closely depends on the co-optation of state actors. The research suggests that, rather than viewing migrants and those who mediate migration in opposition and the state as a benevolent facilitator, they should be analysed as co-constituting human trafficking, debt-bondage, and forced labour. It highlights the need for states to take greater responsibility for their own involvement in creating modern slavery. At the same time, the findings highlight the ways in which migrants use brokerage to exercise agency by taking advantage of irregular migration routes and informal employment.

Keywords: Modern slavery, human trafficking, migration brokerage, migration industry, debt-bondage, forced labour.

\section{INTRODUCTION}

Forced labour, human trafficking, modern slavery, debt-migration, and other manifestations of unfree labour are endemic in global supply chains and the lowest tiers of services and manufacturing in a variety of sectors, including agriculture, construction, fisheries, and plantations (Guérin 2013, LeBaron \& Phillips 2019). We compare the manifestations of unfree labour in migration for low-skilled work in Myanmar and Ghana and examine the role of brokers, the migrants themselves, and the state in creating and perpetuating it. Although in different continents, the two countries have striking similarities in terms of development indicators, both have a 
significant proportion of their populations living in poverty, and migration for low-paid and low-skilled work, such as construction work, work in fisheries, care work, and domestic work, is widespread. The two countries also have extensive networks of brokers, who have emerged in response to inaccessible emigration procedures, increasing restrictions on migration, and are embedded in cultures where economic transactions and trade occur through market intermediaries (Awumbila et al. 2018, Deshingkar 2018, Deshingkar et al. 2019).

The research sought to investigate the inner workings and operational logic of brokers, the state, and employers in positioning migrants in precarious work and creating unfree labour in Libya, Kuwait, Singapore, and Thailand. The focus of the research was on brokered migration for domestic work and construction work because these two occupations are globally important for low-skilled migrants and offer important insights into the specificities of recruitment and placement of workers. According to the International Labour Organization (ILO) (Gallotti \& Branch 2015) and Building and Wood Workers International (a global federation of unions of building workers), domestic work and construction work together employ at least 240 million adults and an equally significant number of children worldwide (reliable statistics for child labour are not available). Migrants from poor and historically disadvantaged social groups and regions are heavily represented in both occupations. Brokerage is widespread in these occupations, as companies extend their reach to ever-more remote locations in search of a docile workforce that will accept exploitative conditions. Both kinds of work have also been listed as occupations of concern in the context of efforts to abolish trafficking and slavery and the worst forms of child labour. Both countries have made serious efforts to eliminate informal brokers in an effort to reduce exploitation. We unpick the relations between private actors (brokers and employers) and the state and its machinery, and labour to throw light on the micro-mechanisms that create unfree labour during the recruitment, journey, placement, and employment of migrant workers. We also examine why systems of brokerage and unfree labour continue to exist, despite efforts to eliminate them, and provide a more nuanced picture of the interaction of structure and agency and the role of brokers within that.

\section{METHODS}

The paper draws on evidence gathered through fifteen months of research in Ghana and Myanmar, involving 215 in-depth interviews with aspiring, current, and returned migrants working as domestic or construction workers, formal and informal brokers, as well as transport providers. Interviewing a range of actors provided a variety of 
perspectives and insights into the infrastructure of brokerage and how different components of the system link up with each other in migration and recruitment systems. By doing so, points of vulnerability and exploitation as well as opportunities for exercising agency were identified. In Ghana, interviews were conducted in one urban area (Accra-Tema) and two rural locations (Nkoranza and Bawku). The Accra-Tema urban conglomeration is an important destination and transit point for migrants who are working to save money before they attempt an onward journey abroad. Nkoranza in the Brong Ahafo region has emerged as a major location for migrants travelling north towards Libya. Due to the concentration of 'connection men', as brokers are locally known, Nkoranza is also a point where deported migrants return and stay if they plan to migrate again. Fieldwork was also conducted in the northeastern town of Bawku because it is an important point along the route for migrants heading up north towards Libya from the Brong Ahafo region and here there are other brokers to help them with their onward journey.

In Myanmar, the research was conducted in Yangon, from where there is significant international migration towards richer countries in Southeast Asia such as Thailand, Malaysia, and Singapore. Although there is a ban on migration for domestic work to Singapore because of reports of human rights abuses, the system of brokerage has found ways of circumventing that. However, respondents were reluctant to discuss details of this migration, so some interviews were conducted by telephone with current migrants in Singapore and Thailand identified through snowballing. Many of the migrants transitting through Yangon are originally from rural areas in Ayeyarwady and other deprived regions. Research was also conducted in Mon and Kayin states, which account for large numbers of men and women migrating to Thailand. Decades of chronic underdevelopment and conflict, as well as the long border with Thailand, have created opportunities for human smuggling and irregular migration in this region inhabited by the Karen, $\mathrm{Pa}$ 'O, and other ethnic groups.

In order to examine the social construction of exploitative relations and unfree labour, it is important to consider the terms of recruitment at the origin, experiences en route, the insertion of migrants into labour markets at the destination, and the overall policy context which determines their legality, rights, and protection. Particular routes and destinations that were commonly encountered in the study areas are discussed to illustrate social relations and power dynamics between different actors at different points of the journey. 


\section{CONCEPTUAL FRAMEWORK}

In framing our argument we draw on three interconnected bodies of literature. First, we discuss key literature which examines the interaction of precarious employment, precarious legal status, and unfree labour, including recent thinking on hyperprecarity as well as the political economy of unfree labour. These areas of debate throw light on how the state creates and reproduces unfree labour and compounds precarity through border control, immigration, and restricted employment policies. We then briefly discuss major works in the rapidly evolving field of migration industry and brokerage research, which provide insights on the inner workings, motivations, interactions, and outcomes of networks and assemblages of diverse actors that together facilitate and constrain mobility and agency. Finally, we engage with the scholarship that analyses the forms and nature of individual agency in highly constrained circumstances that speaks to the situation that we encountered in both of these countries.

There is now a vast body of literature on worker precarity and unfree labour arising from the progressive dismantling of protective employment by economic liberalisation policies (Bourdieu 1997, Standing 2011). While early analyses were focussed on capital-labour relations in the workplace, the debate has now moved on to recognise the role of actors beyond the workplace, including the role of the state in co-creating precarity (Buckley et al. 2017). Research on the geographies of precarity has shown that migrants are especially vulnerable to being employed in precarious work and unfree labour conditions (Basok et al. 2016, Paret \& Gleeson 2016, Platt et al. 2017, Strauss 2017). Their precarity arises not only through employment relations, but also through the interaction of neoliberal labour markets and restrictive migration policies giving rise to what Lewis et al. (2015:3) call 'hyper-precarity'. This can apply even to those who are on legal work permits, as is the case in Singapore (Wee et al. 2018) and the Gulf States through the notorious kafala system of labour recruitment (Deshingkar et al. 2018). Those without legal status are even more vulnerable to becoming precarious and trapped in unfree labour. Menjívar and Kanstroom (2013) draw attention to the extreme vulnerability of undocumented migrants and those with precarious legal status to being deported. Intense surveillance and potential threats of removal create a situation of hyper-precarity that extends beyond the workplace. De Genova and Peutz (2010) see countries that allocate different legal statuses in the form of temporary work contracts and permits with strict rules of residence as 'deportation regimes', a feature of many migrant-receiving countries. This strand of work resonates with recent research on the political economy of unfree labour. LeBaron and Phillips (2019) critique existing analyses which focus on capital and labour without systematically analysing the role of the state in the production 
and reproduction of unfree labour through 'causal and multifaceted roles in creating the conditions in which unfree labour can flourish' (1). Like Lewis et al. (2015), Menjívar and Kanstroom (2013), and De Genova and Peutz (2010), they train the spotlight on the interaction between labour market regulations, migration regulation, and business regulation in shaping unfreedom among migrant labour. The added value of LeBaron and Phillip's critique for our work is that it allows us to explain the multifacetted and often contradictory roles played by the state. While one aspect of this is to immobilise labour through immigration and employment policies, other dimensions of the interaction of the state with brokerage are through the rent-seeking activities of officials at checkpoints and passport offices. There are now calls for states to take responsibility for their own involvement in the production of unfree labour and modern slavery. Webb and Garciandía (2018) distinguish between different modes of state involvement, including informal involvement through corruption and state-sanctioned systems of brokerage and human trafficking, on both of which we have ample evidence from Ghana and Myanmar.

Exactly how precarious labour, precarious legal status, and unfree labour are connected is now a matter of intense debate. Strauss and McGrath (2017) call for a conceptualisation of the unfreedom experienced by migrants along a continuum of labour relations that highlight the interrelationship between restrictive immigration regimes and unequal power relations in labour markets. In a similar vein, Anderson and O'Connell Davidson (2003) urge us to view people's experience as a continuum of exploitation, abuse, powerlessness, and restriction rather than a black-and-white situation of exploited or free. Lerche (2007) takes a similar position in his essay on free and unfree labour, which he conceptualises as a continuum rather than two polar opposites.

But the role of migration intermediaries, namely brokers and the wider migration industry, in shaping unfree labour remains under-researched. However, there has been considerable interest in migration brokerage and its various forms, including smuggling, to produce a better understanding of why and how these intermediaries have emerged and how they operate. While early scholarship focussed on brokerage as a business and on brokers themselves as the main actors in migration mediation (Salt \& Stein 1997), recent scholarship has broadened the understanding to include a variety of actors, from individual entrepreneurs, large corporations, secular and faith-based non-governmental organisations (NGOs), to organised criminal networks involved in human trafficking, which are involved in the business of migration or the 'migration industry' (Gammeltoft \& Sorensen 2013, Hernandez Leon 2005).

The reasons for the emergence of brokerage networks are extremely context specific, shaped by the interaction of the state, labour markets, and private actors. Research in different countries has revealed these specificities: for example, in wealthy 
migrant-receiving countries in Southeast Asia, brokers have emerged to assist migrants with the navigation of complex immigration regimes (Lindquist et al. 2012, McKeown 2012). In countries of origin, brokers have also emerged because of the inaccessibility of the state and its formal procedures, but also to assist remote rural communities which have limited knowledge of transport routes and networks (Lindquist 2012). Research in northern Thailand conducted by Sobieszczyk (2002) found that informal brokers are often chosen because the entire process of obtaining papers, travelling, and finding work is much faster than migrating through legal channels (5). The same was seen in northern Ghana, where brokers were preferred over legal channels (Lucht 2013). Brokers are also present in labour source areas from where industries seek to recruit workers who are prepared to accept exploitative conditions (Guérin 2013, McCollum \& Findlay 2018, Tyner 2004). Different brokers are present in transit locations who assist with temporary sojourns and finding work, onward journeys, communication with families, and the transfer of funds (Ayalew et al. 2019).

The economic and social relations between different components and tiers of the migration industry have been identified as an area requiring further inquiry (Faist 2014). Xiang and Lindquist (2014) use the analogy of flying, which involves multiple structures, networks, institutions, and technologies, in their analysis of the 'infrastructure' of migration or systematically linked institutions, actors, and technologies that condition and facilitate migration. They stress this collective interaction: 'it is not migrants who migrate but rather constellations consisting of migrants and non-migrants, of human and non-human actors. This is increasingly obvious today, as more than ever before, migration is intensively mediated' (S124). Understanding the logic of these components of the migration infrastructure and how they collide and become entangled with each other is key to understanding the specificities of migration mediation in different contexts. Schapendonk (2017) interrogates the different actors and their roles, drawing on the concept of assemblages (Deleuze \& Guattari 1987) to argue that they can be in conflict but also overlap, blurring the boundaries between them.

Indeed, as the findings presented here show, brokers and other actors involved in migration in Ghana and Myanmar appear to respond in these complex and overlapping ways.

With the growing complexity of brokerage networks that has gone hand in hand with tightening restrictions on mobility, there has also been a sharp increase in the cost of migration. Those wishing to migrate to Europe from Ghana are paying anywhere between eight and ten thousand dollars. Myanmar migrants travelling to Singapore can also end up paying thousands of dollars (Goh et al. 2016).

In policy debates, the rising costs and the proliferation of brokers have been taken as indicators of a ruthless profit-making business, where exploitation and extraction of cheap labour override any altruistic motivations. Ethnographic research on brokers 
problematises this. For example, extended immersive research by Osella (2014) and Osella and Osella (2009) among migrant communities in Kerala discusses the reasons for migrants placing their trust in brokers. For them, brokers are more credible and hold the promise of fulfilling their migration project, which is to be delivered in the Gulf States. Whether or not they are regarded as illegitimate by the state, is not of concern to the migrants. Similar findings have emerged from the research by Alpes (2013) in Cameroun.

Complicating the picture is evidence that brokers are integral to migrants being able to exercise agency - by transcending local power inequalities, by accessing more remunerative work, and by switching jobs at the destination (Awumbila et al. 2018, Deshingkar 2018, Deshingkar et al. 2018, Picherit 2018, Wee et al. 2018). In other words, migrants are exercising agency in highly constrained situations and brokers are a key part of their strategies for self-development, as we discuss next.

\section{AGENCY IN BROKERAGE RELATIONS}

Migrant agency in contemporary forms of mobility has been extensively researched (Castles 2002, Goldring \& Landolt 2011, Rogaly \& Thieme 2012), but the ways in which brokers help migrants extend their agency remains poorly understood. Efforts to classify agency in terms of its transformative effects on structures of inequality have distinguished between small acts of resilience and resistance, which may provide ways of coping with oppression and some improvements in working conditions, and, on the other hand, those which can rework power relations (Katz 2004). A few studies have unpicked the specificities of migrant agency within brokerage, covering various possibilities described by Katz, and distinguish between (a) the extension of migrant agency by brokers, wherein they assist migrants in transgressing local socio-economic boundaries by moving away, and (b) the potential for brokerage to offer opportunities for resistance against unequal power relations at the destination and a shift in subject positions over time. The first is relatively better researched in relation to migration (Cranston et al. 2018, Gammeltoft-Hansen \& Sorensen 2013) as well as migrant smuggling (Van Liempt 2007, Van Liempt \& Doomernik 2006, Zhang et al. 2018). Van Liempt and Doomernik's (2006) research on migrants smuggled into the Netherlands from Iraq, the Horn of Africa, and the erstwhile Soviet Union challenges the idea that migrants have no agency in the process of smuggling. They highlight the varying degrees of autonomy that migrants have in deciding where and how they want to travel, but stress that they ultimately remain vulnerable to exploitation.

There is a smaller and evolving field of work on brokerage itself being part of migrants' agential strategies. This examines the different ways in which brokers assist 
migrants with performing ideal migrant roles, integration at the destination, bargaining with potential employers, and switching jobs. Wee et al. (2018) unpack broker practices in recruiting and placing domestic workers in Singapore to show how brokers create vulnerability and precarity through 'chutes' that the migrants can fall into, but also possess the power to patch up these chutes and set migrants onto ladders of upward social mobility. The authors discuss the issue of the discretionary weekly day off for migrant workers in Singapore, which has been left to negotiations between workers and employers. Agents may open chutes by hiring only those workers who are willing to give up their days off. The uncertainty of the route for migrants is created by opening and closing of chutes and distributing precarity between the different parts of the migration industry. In Ghana, urban brokers are a critical source of material support for newly arrived rural girls and women in the city (Awumbila et al. 2018). Thus brokers play complex and contradictory roles: they are part of the system that reproduces precarious and unfree labour but, at the same time, they also help with opportunities for exploring the job market in Accra where guarantors and character references are needed. Brokers also assist migrants with switching jobs and moving up the job ladder, but whether or not they do so depends on how they evaluate the migrants' attributes and character and the strategies that the migrants themselves employ to convince the brokers to act on their behalf. These findings chime with the research being presented here for Myanmar migrants in Singapore and Thailand.

Implicit in some of the scholarship on migrant agency and brokerage are aspects related to time. This is because agency in highly constrained situations can transform the social and economic position of migrants and their families gradually, but over an extended period of time. While the importance of considering temporalities in the analysis of migration has been stressed in a number of studies, it has taken varied positions. Some researchers, including Rogaly and Thieme (2012) and Robertson (2014), highlight non-linear and complex journeys with varied durations, stages, and hazy boundaries between temporary and permanent migration. Others have tried to conceptualise the spatio-temporal reorderings and transformations that migrants experience through an analysis of migration dynamics in the past, present, and future, drawing on life-course theories (Bailey 2009, Hopkins \& Pain 2007, Kobayashi \& Preston 2014). Only a handful of studies explicitly analyse the temporality of migrant agency. Among these are Bastia and McGrath (2011) as well as O'Connell Davidson (2013), who argue that crippling debts and unfree working conditions in the present may be suffered to gain freedoms in the future. In other words, migrants are 'mortgaging' the present to reap benefits in the future (Bastia \& McGrath 2011). Perhaps this is why nearly all the situations that are described as slavery in modern societies today involve people voluntarily and actively seeking out those opportunities, as Brace and O'Connell Davidson (2018) observe in their recent volume on slavery. Recent studies 
by Deshingkar et al. (2018) on the migration of Bangladeshi construction workers to Qatar, and Johnson (2018) on the migration of domestic workers to the Middle East also find that the discourse on forced and unfree labour fails to recognise opportunities for agency that may arise, albeit in heavily constrained conditions. The concept of 'constrained agency', proposed by Coe and Jordhus-Lier (2011) and applied by Carswell and De Neve (2018) among others, is also useful here. These scholars analyse the gendered subject positions of workers in migrant labour markets and examine their agency against their social and economic background. The entry into debtmigration by migrants from Myanmar from extremely poor families who agree to forgo months of wages can be understood when compared with the extremely limited options back home, which may be considered worse.

\section{THE INFRASTRUCTURE OF MIGRATION AND MIGRATION JOURNEYS}

Community discourses in the research locations suggest that the prevalence of informal brokers has mushroomed over the last ten years. Informal brokers, known as 'connection men' in Ghana and 'Carry' in Myanmar, work with transport agents, immigration and border officials, as well as national identity and passport authorities. In both countries, the first move was often made by the migrant or migrant's friends or family in finding a broker with a reputation for delivering migrants to a particular destination or job. The first act of the broker is usually to discourage the migrant from doing anything themselves once they have decided to go with the broker and thus to surrender to choices made for them by the broker. In the case of persons intending to migrate irregularly to North Africa from Ghana, brokers were largely responsible for acquiring passports and organising the entire trip through the desert. In the case of migration to the Gulf States from Ghana, the brokers were largely responsible for identifying vacancies, acquiring visas, and providing training for the potential migrants. A similar pattern was seen in Myanmar, where brokers arranged the journey for migrant construction workers, whereas their involvement in the migration of women for domestic work was greater and more controlling. As in Ghana, they identified jobs, procured visas, and provided training and places to stay en route. In this way, informal brokers play a critical role in selecting and filtering workers who can be placed in exploitative work. Brokers source girls and women who are docile, poorly informed about migration and the labour market at the destination, who come from deprived backgrounds, and are more likely to accept forced labour conditions (Tyner 2004). They collude with employers who are sanctioned by receiving-country governments to employ migrant workers under debt-bondage conditions to limit their spatial mobility and extract cheap labour. The functioning of brokers in this type of 
channelling and placement has been documented in extensive research in other parts of Asia (Rodriguez \& Schwenken, 2013). What was also striking about brokers' roles in migration for domestic work was that they were also involved in the choice of destination country, indicating that they channelled workers into places where their own networks extended. As Nyunt, a return migrant from Singapore who was interviewed in Yangon said:

They told me that Singapore is better and safer. I didn't have any money with me and my family didn't know about this. They said that I will have to pay for the medical check-up and the agent will pay for other things. So, I was happy. They gave me contact numbers, an address card, and email addresses for both Myanmar and Singapore companies so that I can contact them if I get into trouble.

The broker will try to reassure the migrant that they always fulfil their promise and may mobilise others who have migrated through them to build up their case:

You know after listening to the agent and those ladies over there, I was convinced that it was the right thing to do. The agent made me talk [on the telephone] to some ladies who were already there. They all said positive things about the work there, but never told me the work was that tedious.

Alex (return migrant, Nkoranzah)

However, a majority who use the services of brokers are given incomplete or false information about the journey, as well as about the jobs they are going into and the terms of their employment and living. Brokers at the origin are often part of chains of brokers along the route and all the way to the destination. While village-level brokers may claim no knowledge of exploitative practices further up the chain, once the migrants are in their control, they are at the start of a process that places them on an exploitative trajectory.

It was also common for brokers to declare the total amount they would charge to deliver the migrant to an agreed point. While potential migrants were usually expected to pay upfront, it was also seen in both Myanmar and Ghana that some were offered more flexible arrangements. These arrangements are either when a 'sponsor' at the other end, a relative or friend, promises to pay the broker after the migrant has been delivered safely or, as in Nyunt's case, when the broker, together with the employer, pays all the transport charges, work permit charges, and any other costs, and recuperates them through salary deductions.

Once at the destination, workers are often prevented from leaving by confinement, threats of violence, and confiscation of documents, as the experience of domestic workers shows. At the same time, the accounts also indicate that there is a need to better understand how migrants agency is being exercised in such extreme situations of exploitation. 


\section{GHANA TO LIBYA FOR CONSTRUCTION WORK}

Libya is, by all accounts, a failed state where the lack of a clear government and labour protection has created a situation of lawlessness (Ware 2018). There appears to be no legislative and administrative framework for managing migration and smuggling that adheres to international frameworks. Armed militia roam the streets and shoot and rob people at random. Despite this, Libya is a favoured destination because of the remunerative work opportunities as well as opportunities for onward travel to Europe, as highlighted in the statement below by an aspiring migrant:

I wanted to travel to Europe to hustle and make money to help my family. You know in Ghana there is no job and things are hard, even when you go to university and finish it is difficult to get a job. I have friends who have passed through Libya and are now in Europe so I was in close contact with them so they keep telling how good it is come to Europe.

Sam (current migrant in Libya)

Kevin said he went there to work to save money to go to Europe but was content to be in Libya, even though he did not make it to Europe.

I knew I didn't have money to go to Italy or Spain. But I knew when I get to Libya things will be okay.

Kevin (Return migrant, Nkoranzah)

An aspiring migrant, Bob, said he was also planning to go to Europe via Libya:

I want to migrate to Germany, yeah, but I will use it through Libya to Italy and then seek asylum then to Germany because a lot of my friends are over there. Because I learnt over jobs are earning the workmanship is good you understand.

Bob (aspiring migrant in Bawku)

As shown in the statements above, these migrants are inspired by cases like those of Mustafa, a current migrant in Germany, who had worked in Libya for several years before travelling to Germany.

\section{Migration via the desert, re-migration}

Some migrants had been deported and had re-migrated through extremely dangerous routes multiple times. Given the situation in Libya, this was surprising, but the risks and routes of irregular migration were well known in Nkoranzah and Bawku. Kevin, a migrant from Nkoranzah, described his reasons and experiences of repeat migration to Libya three times via Bawku, Niamey, and Agadez, paying connection men and border officials (it is not clear what kind and whether they were actually official) at 
each stage. The connection men in the transit towns were well known in Nkoranzah and he had their names before he left. His friends had prepared him for the journey: he had taken gari (a foodstuff made from cassava) to avoid starvation, glucose for energy during rough journeys on foot, as well as West Africa CFA francs to pay at different borders.

I met four connection men. Bawku, Niamey, Agadez, and then the one in Libya. When you meet them, you will pay them. Then they will get you some place to sleep and find a vehicle for the continuation of the journey. Then they will also get you some food.

Kevin (return migrant, Nkoranzah)

He appeared to view the relationship with the connection men as reciprocal and supportive rather than one of control and subjugation. The broker's responsibility ended just before the Libyan border and they instructed the migrants to manage by themselves. That last leg of the journey was the riskiest, as they had to walk through territory with armed gangs who rob migrants with impunity. Those without money are handed over to the Libyan police. It was not clear whether these were actual police, as it was entirely possible for imposters to engage in such extortion in a situation of complete lawlessness.

We went through Hoggar, ${ }^{1}$ We had to walk. We spent two weeks and four days at Hoggar. We were living on the mountain, there were no houses at that place so we slept on the stones. We met armed robbers. They will make you to undress and kneel down. They will take all your money. I was told it was a scary journey and truly, it was very scary. You will meet dead bodies on the desert, and even at Hoggar you can easily be killed by the armed robbers. I saw dead bodies, I even collapsed at Hoggar.

Because we did not have money, we were imprisoned. The Libya police arrested us and imprisoned us for four months, all this while you will not bath. You are given water once a day to drink which is even salty. We were from different countries in the cell. We were many. Each room had about 100 people. Both male and female. We were many. We had to call home and ask for money to bail us. So when the money came I used that to pay the police before I was released. I had to call a brother of mine who is a fitter in Ghana to send me the money.

This pattern of extortion from migrant families has been widely reported in the media and in recent research as well (Van Reisen \& Rijken 2015). Kevin gradually made his way to Tripoli via Saba, stopping and working along the way. Once in Tripoli,

\footnotetext{
${ }^{1}$ A large plateau in the north centre of the Sahara, encompassing the Tibesti area of Libya. An old caravan route passed through this region.
} 
he was quickly put to work by the connection man there. He started earning 1,500 Ghanaian cedis ${ }^{2}$ a month and began sending remittances immediately.

So my first savings I sent it my mother to build the house. And my brother who was a mason I helped to join me. Then my siblings had completed senior secondary school so I sent money for them to go to training college.

But one of the employers betrayed him to the police and he was arrested once again and deported back to Ghana after a month. Despite these events, Kevin decided to try his luck again a year later with financial support from his family. He regards his migration as a success for the family.

Now I have siblings in Italy and the other brother is in Libya. Some are teaching and some are in school. I didn't get everything, but by the grace of God I have been able to put up a house which was part of my main aim for travelling so I'm satisfied.

Kevin and others like him are placed on trajectories into extremely precarious and uncertain journeys, not knowing when they will be caught, imprisoned, robbed, or deported. Even those who had successfully remained in Libya were working under conditions that can only be described as unfree labour.

Although aiming to ban informal brokers, the Ghanaian state has no mechanism for managing or regulating informal brokers. While government is no doubt aware of the operations of connection men, its main response has been to criminalise them without introducing realistic ways of regulating them to reduce migrant vulnerability. On the other hand, the complete breakdown of the state in Libya and the outsourcing of European border controls by bolstering the deportation system without protecting migrant rights has left migrants from Ghana at the mercy of armed gangs and criminal employers who extract labour without paying.

\section{MON TO THAILAND FOR CONSTRUCTION WORK}

The context of migration for construction work is altogether different in Myanmar. Compared to Ghana, migrants from the conflict-ridden, poor state of Mon towards neighbouring Thailand for construction work were far less educated and much younger. Most of our interviewees came from extremely poor families, where both men and women were migrating for construction work and most were educated to 4th or 5th standard and not in regular work before they migrated. Thailand has recently introduced several measures to curb irregular migration and limits the rights of migrants in the country. It places restrictions on the right to travel, or change

\footnotetext{
${ }^{2}$ The exchange rate was roughly 5 cedis to the US dollar.
} 
employers, and through the Thai Labour Relations Act (B.E. 2518 (1975)), prevents non-Thais from forming unions. However, as the cases below show, brokers and the state machinery are deeply involved in maintaining irregular migration and unfree labour.

Due to long-standing political and economic instability, Mon youth see migration as a rite of passage and the only way of achieving a transformation in their economic conditions through the purchase of land, building/renovating houses, or starting a business. Female migrants working in construction often come from extremely poor families, where there are no older male siblings to migrate and support the family, as is the case with Simi, a current migrant. She is the eldest daughter in a poor family with three younger brothers. She decided to migrate to build a future for her son and support her parents.

For my child. For his development, prosperity, to be educated, to be able to attend school. I have to support my child. I have seen other people going and I wanted to go. I have seen other people sent money to their parents, so I wanted to look after my parents. That's why I came.

A majority migrate through known brokers and feel better protected through them, as narrated below by Simi:

That time, people had to go illegally. So, it will be safer to go with broker. Besides, I couldn't speak Thai, it was better to go with broker.

Simi (current migrant border town near Malaysia)

If I come by myself with car it is difficult. As I was alone I could be left. If by the broker it was with other people so it was easier. It cost 1,500 baht ${ }^{3}$ more, but I wouldn't face trouble. So I came with broker although it cost more.

Myint (current migrant Phuket)

When we had to pass the Thai police gate, he [broker] just met them [border police] himself. We didn't even go out from the car.

Mary (current migrant Phuket)

\section{Costs}

On average, migrants from Mon paid 30,000 kyat ${ }^{4}$ to brokers to cross the border to Thailand and then another 1,200 baht for onward journeys. These costs were usually financed through borrowing from relatives. Nearly all crossed the border illegally without any documents, but then regularised their status after a period of time,

${ }^{3}$ There are roughly 30 Thai baht to the US dollar.

${ }^{4}$ The exchange rate was roughly 1000 kyat to the US dollar. 
borrowing money from employers and obtaining documents through brokers. They either migrate to a known job or find work immediately and switch jobs easily, sometimes with the next boss releasing them from debt or easing their hardship by offering advance payments. The usual pattern is for them to obtain official permits after they have repaid their initial debts and after trust has been built up with the boss. The boss then lends them the 8,500 baht needed for a 'Thai passport' and this is recuperated through wage deductions but on flexible terms that suit the worker, taking into account his or her needs.

\section{Irregular status risks, advantages}

The irregular status of migrants means that they are extremely vulnerable to being cheated. Cases of no pay were common and there is no legal recourse.

What could I do? I didn't have any passport and I couldn't speak Thai. So I couldn't do anything about it, except move to another place.

Mary (current migrant)

All through her migration, Mary had no contact with the Thai authorities at all, which was typical of migrants in her situation.

I had to give 500 baht every month. I gave the boss and he gave the policeman. He just said that for the worker who doesn't have passport there is a tax to the police of 500 baht a month to get the permission to live and work their country. So we have to do it. If a worker was caught without documents, the boss released them.

From Mary's perspective, bosses like hers were 'good' because they got her to her destination and protected her against the law there. Brokers and bosses operating below the law were crucial to the migration project of many of the migrants we interviewed, as they wanted to remain irregular, as they would not have limits on the time period of stay and could work in the informal economy where there were possibilities for changing employers.

Migrants use a variety of strategies to overstay in Thailand, which often involve brokers who have contacts with border officials. One such method is the ghost stamping of passports.

Nyein is a Mon Buddhist who started migrating to Thailand to work in construction where many of her relatives were already working. She has managed to stay there through the system of passport stamping, where the broker carries the passport while she remains in Thailand.

From this route they stamped the seal on the passport. So even if I didn't want to go back within one year I can stay here [in Thailand]. 
Once the debts incurred by the family to finance migration as well as the debts to the employer for obtaining passports and permits have been repaid, migrants can start to save and remit in substantial amounts, as was the case with Mimi who had been remitting between 100,000 and 150,000 kyat to her mother and is saving the rest to buy gold.

\section{MIGRATION FOR DOMESTIC WORK}

Debt-migration was highly prevalent in this kind of migration, either because women ${ }^{5}$ entering such migration belonged to very poor families or because they had decided to leave without the backing of their families and did not have enough savings to pay upfront. The Gulf States are notorious for the 'kafala' system of labour recruitment, which ties workers to kafeels or sponsors of their visa and work permits. The kafala system also ties migrants to a single employer and gives hardly any rights to challenge working conditions (Fernandez 2013), and has been held responsible for the widespread abuse of workers' rights in the Gulf States. Although reforms to the kafala system were introduced in 2016, domestic work was not brought under the new structure, leaving workers vulnerable to neo-slavery (Parreñas \& Silvey 2016). Employers are still bestowed with extensive powers of control, including not granting release to an employee and limits on mobility. Migrants are prime candidates for brokers to channel into 'state-sponsored bonded labour' arrangements that Franz (2013) speaks of in her essay on domestic workers in Jordan. State regulations in Singapore have also created the conditions for extreme labour exploitation and a migrant workforce with few civil liberties and rights. Singapore has a two-tier system for skilled and unskilled migrant workers (Baey \& Yeoh 2018). The regime has been criticised for creating hyper-precarious conditions by allowing employers and the state to collude over punitive debt-bondage arrangements (Platt et al. 2017), as well as the regulation of the residence and reproductive rights of migrants (Huang \& Yeoh 1998). The power to create worker precarity and vulnerability is in the hands of employers and brokers who place them, and it is up to them whether they choose to worsen or mitigate these risks and hardships (Wee et al. 2018). Until recently, workers were not entitled to any days off and, although legislation has been introduced to encourage time off, it is still left to the discretion of employers. Thailand places restrictions on the right to travel, or change employers, and through the Thai Labour Relations Act prevents non-Thais

${ }^{5}$ Globally, domestic work is female dominated because work within homes is typically regarded as 'women's work'. 
from forming unions. Women employed in domestic work are excluded from the 1998 Thai Labour Protection Act (B.E. 2541; see Carden 2014).

Both countries have banned certain kinds of labour migration: the government of Ghana banned labour migration to the Middle East in 2017 and Myanmar has an ongoing ban on migration for domestic work to Singapore. Despite this, such migration continues, but it has been pushed underground and occurs through informal brokers and irregular routes. In Ghana, brokers often take longer routes through neighbouring countries rather than flying directly to the Gulf States to avoid detection. The cost of migration for domestic work has increased in both countries in the context of migration bans. Brokers have to pay for transport, bribes along the way, and in some instances work permits (the costs for these could be shared by the employer). Such migration in both countries was highly structured and heavily controlled by brokers from the moment the women left the house. Control was exercised through restrictions on spaces of travel, transit, living, and working, and the confiscation of passports and mobile phones. Heavy control is most likely because brokers and employers must ensure that their advances are repaid. Below we discuss some specificities of broker practices in Kayin, Yangon, and Ghana.

\section{KAYIN TO THAILAND FOR DOMESTIC WORK}

Kayin is known for the migration of domestic workers to Thailand, and this pattern has resulted from social networks and established migration streams. As was seen in the case of Mon construction workers, the prevalence of informal brokers was widespread.

31-year-old Hla is a typical migrant domestic worker from the region. She comes from a subsistence farming family in a village near Hpa-An in Kayin and had migrated to Thailand three times since 2007. She decided to migrate after failing her 10th exam twice, as she saw no future in the village. Her cousin put her in touch with an informal broker in the village who was recruiting for domestic work in Bangkok. She borrowed from her aunt to pay 500,000 kyat for the entire package, which included all the necessary documentation and a safe crossing.

The journeys of female domestic workers were far more hazardous than those of construction workers. Although none of the respondents reported sexual harassment or abuse by the brokers, they experienced deception and physical confinement, with one saying she was drugged by the broker so that she could be smuggled across in a container.

Hla was taken to Thailand in a group of twenty-eight who were also being smuggled via Meh Tha Waw, and described how the journey was not at all what she had expected. 
We were packed into the car. I was very afraid, I couldn't control my tears. I was afraid and I missed my parents. We had to sleep in the forest. We had to hide. It was raining and mosquitoes bit us. The food was not good; the water was unclean. We were kept in a cage. The car was covered with tarpaulin and twenty-eight people were packed. All male, female, were kept together.

The $500 \mathrm{~km}$ journey to Bangkok took ten days with several stops and hideouts along the way. Hla caught cerebral malaria and nearly died.

Her subsequent trips were with a variety of Carrys - the second time the Carry was a Thai policeman, but the subsequent trip through Myawaddy was another kind of Carry who administered a drug to put her to sleep through the journey.

She [Carry] gave me a sedation drug. I thought I was dead. When I regained consciousness she had sent me to Kyar wah Tar. We had to sit in a row and dared not make a noise. There was no light. It was dark. We had to stay like that. They gave us a small amount of rice and half of boiled egg. We were all distressed.

Similar stories of extremely hazardous journeys organised by brokers emerged in the other interviews. Htet reported how she was hidden in a secret compartment at the back of a duck enclosure in Myawaddy. Others described being transported in compartments at the bottom of trucks full of vegetables and feeling terrified when the border guards thrust spears through them to detect people.

\section{Working conditions at the destination}

Not having formal or legal contracts that specify the conditions of work or migrant rights was the norm, and this created room for deception and cheating. When Hla arrived in Bangkok, the job turned out to be less than she had expected:

During the interview they said that I will have to work 8 hours a day. When I went to work, the work didn't finish from morning 5 AM to 7 PM. And then they told me that they will give me 10,000 baht. When I arrived there, she gave me only 8,000. There are many bosses who are not good. They didn't allow me when I asked permission to go out. If I go out they accused me of sneaking out. Recently, I have asked the boss for resignation, but she didn't give me.

Other research by Kusakabe and Pearson (2010) on Myanmar women in Thailand also highlights their precarity and vulnerability. Despite her experiences, Hla remigrated twice through informal brokers because she wanted to re-enter the informal labour market without being restricted to one job. 


\section{Strategies to remain in Thailand}

Here, too, migrants were using brokers who had contacts with border officials to enable them to stay in Thailand. Another domestic worker from Kayin (Cho) spoke of the system of passport stamping, where Carry and drivers would take the passports of Myanmar citizens to have them stamped at a certain 'gate' in Mae Sot. For 5,000 baht they obtain stamps showing that the migrant had returned, but in fact she had stayed in the country all the time.

The first seal [stamp in the passport] was for coming back to the village. This seal was for entering Thai[land]. This is for re-entry seal. For the seal, the broker did it. [return]. They have to do the seal for the return. The broker did it. Yes, there is a gate at Mae Sot.

Hla described a similar process:

They took the passport from Burmese who came back from Myanmar. They took the picture that was similar to me. They gave the police money at every step and at the gates. I didn't need to be afraid. I didn't need to hide. I could come freely. When we have a similar face, we can hold the passport and come. We had to tell the name in the passport. But the police didn't ask me. They [Carry] have already given the money to the police. There were five gates from Mae Sot to Bangkok.

Htet paid on average 500,000 kyat each time she travelled in this way. In the two years that she had stayed there, she changed jobs three times because of issues related to non-payment of wages, accusations of sneaking out, and not being treated well when she was sick. Through local Carrys she was able to find different jobs and at the time of the interview she intended to stay in Bangkok until she finishes building her house at home.

The complicity of border officials in the process is evident. On the one hand, the state is positioning itself as the sole legitimate facilitator of migration and protector of human rights. But its officials play a dual role, as they are embedded in the system of irregular migration and the rents that it brings.

\section{GHANA TO THE MIDDLE EAST FOR DOMESTIC WORK}

Saudi Arabia, the United Arab Emirates, Qatar, Jordan, and Kuwait are the most popular destinations for Ghanaian labour in the Middle East. Most of the women who travelled for domestic work in the region were recruited by private recruitment agencies and connection men. Abi is a 27 -year-old Ghanaian migrant, who had returned from Kuwait after a four-year stint from 2009 to 2013. She decided to migrate because of her parent's failing business and their inability to provide for five children. 
Her original desire was to migrate to Canada and she found a broker through a connection of her aunt's. The broker verbally promised to send her to Canada for 4,500 cedis and told her she would earn 1,500 cedis a month and have a day off every week. But just three days before departure he told her she was travelling to Kuwait, by which time she was trapped in the arrangement.

With three or four days for me to move that was when they called us again to come to Accra and we came. They gave us some paper and I realised that no, this is not where they said I am going to. So that day I was really angry and I didn't want to go but they were like they have already spent the money. So what I thought was that, it means even if I should be around the following year I can't go to school because I had already spent the money and the little that my mum and dad is already added so I have no other option than to go.

This kind of deception was mentioned in other interviews as well and migrants have no legal recourse against them. Although the Ghanaian government has taken extra measures to crack down on unscrupulous brokers, they continue to operate because they represent the only real hope for migrants with low levels of education gaining entry to countries in the developed world.

\section{Informal contracts and extractive work at destination}

As in the case of Kayin migrants, working conditions at the Gulf States were highly exploitative and migrants often found themselves being deceived with little recourse to legal complaint mechanisms. The conditions of work at the destination were different from what brokers in Ghana had verbally promised the migrants. The 'paper' Abi signed just before departure from Ghana demanded that she pay the broker another 1,500 cedis after she reached Kuwait. It did not mention wages or working conditions. Just before boarding, her mobile phone was also taken from her, creating further feelings of isolation and anxiety. After a twelve-hour wait at Kuwait airport with no information, she was eventually taken to her new employer. There she was expected to do all the washing and cleaning, starting at 7 in the morning and finishing at 10 every night. There were no days off, as verbally promised, and she was paid a third of what she had expected. She was not allowed to go out and was allowed to call home only after four months. Han, a 26-year-old Ghanaian woman who has since 2014 been working in Saudi Arabia as a domestic worker reported similar exploitation by her employers. 


\section{Brokers for switching jobs}

Although many of the female domestic workers in the Middle East reported that it is very difficult to switch jobs because of the kafala system, which tends to tie migrants to a single employer, some of the domestic workers reported that they switched jobs with the help of brokers. For instance, after a year of miserable working conditions Abi told her employer she would not stay and he returned her to the broker's office. There she met other brokers who promised to find her work 'outside'. Outside was a way of referring to working outside the contract system.

When I went to the [broker's] office I met some friends who gave me some contacts for working outside. That was how I got connected to some people and later on they gave me help. Some are Ghanaians so they gave me their numbers and a taxi driver's number.

Abi was effectively challenging state-enforced immobility. During her four years in Kuwait, Abi changed jobs at least four times through such informal agents. Similarly, Han and Har, who were Ghanaian domestic workers in Saudi Arabia, reported that they managed to change employers, with the help of brokers. The domestic workers reported that, while the general conditions of work in the Gulf States were bad, they were able to save some money. For instance, while Abi described problems with all of the jobs, such as being overworked or having sore hands from hand-washing clothes, she said she had managed to remit and save 10,000 cedis for herself as well as spend money on renovating her grandmother's house and paying for her younger brother's school fees and her mother's needs. At the time of the interview she was thinking of either attempting a journey to Germany or opening an import business in Ghana.

\section{MYANMAR TO SINGAPORE FOR DOMESTIC WORK}

The situation of Myanmar domestic workers in Singapore was by far the worst, in terms of confinement, isolation, and forced labour extraction. The interviews show various arrangements - some along the lines prescribed by MOM (Ministry of Manpower, Singapore) where workers are placed by formally registered agencies after the necessary health checks have been conducted and work permits have been obtained; others with a degree of irregularity in the implementation of the arrangement; and some that were completely outside the legal system. As was the case in Ghana, many of the domestic workers who took the decision to migrate because of economic problems relied on brokers who exploited them, but also helped them realised their dreams. For instance, Phyu had decided to migrate to Singapore because her alcoholic husband had run up heavy debts and she had no way of supporting her three children. 
She found a female agent in Yangon who promised to take her on a standard debt-migration contract. She mentioned signing a contract in English and not being given a copy. She was also not allowed a mobile phone and made to work in two houses instead of one on the same contract. But the job allowed her to extricate herself from debt in Myanmar.

The case of Nyunt also demonstrates the exploitation and agency of domestic workers from Myanmar. She migrated from Yangon to Singapore in 2008 because she wanted to work abroad to support her parents back in the village and educate her brother. Although she, like many others in our study, left without telling their families, her agency needs to be seen as relationally constituted rather than an autonomous decision, because it was shaped by the needs of her family and the duty expected of daughters in Myanmar. She found a broker through her uncle's wife and was taken to a fancy-looking office in Yangon where they explained how the agent would pay for everything. They made her sit for the MOM test and gave her an offer letter which she later realised were fakes.

She was made aware of monthly deductions to pay off the agent, but was confused about how much she would earn. She did not challenge them as the contact was through her uncle and in Myanmar culture that would have seemed rude. After arrival she was taken to a facility that was clearly operating outside Singaporean law, as she and other girls from Myanmar were locked inside while the agents found prospective employers. She was eventually selected by a Chinese employer who imposed extremely harsh working conditions and restrictions on her. Her work day started at 4 AM and she was locked in her room at night. She was told that the employer would keep all of her wages for ten months.

She said that I will get 60 dollars per month and she will save that money for me and she will give it back when I go back. She asked me how long am I going to get that 60 dollar per salary and I told her that it would be for a year. She said she is going to cut 10 months out of 12 months from the salary. So, when 10 months' salary is cut out of 12 months I will get only 120 dollar working for a year.

The employer began to cut further amounts from her salary for the smallest things, including postage stamps and telephone calls home. After suffering mental trauma and self-harming, the employer returned her to the agent in Singapore who promised to find her another job. But once again she was placed in an extremely exploitative situation. She eventually managed to escape to a police station from where she was sent home to Myanmar. Although her actions which led to her change of employers and escape can be interpreted as agency in extremely constrained circumstances, the outcome for her was not emancipatory or transformative in any way. 


\section{CONCLUSION}

In this paper we have shown that migrants' experiences are shaped by interaction with the governance context within their own country, as well as with the countries of destination. While Ghana has a democratically elected government which is making serious efforts to improve its track record on human trafficking and migrant exploitation, it is complicit in systems that produce precarity and unfree labour, because it has failed to develop effective measures to eliminate exploitative practices. Myanmar, by contrast, is ruled by a military-led government where the state is characterised by surveillance and control. There the state is informally involved in brokerage through corruption and rent-seeking, as well as by turning a blind eye to brokerage and human trafficking. The impunity with which border control officials are involved in the brokerage and trafficking business in Myanmar suggests that this is made possible because of the powerlessness of ordinary citizens vis-à-vis the state.

Our findings also clearly show that strict immigration and employment regimes in migrant-receiving countries make legal migration much more difficult, especially for people from poor societies. Irregular migration was therefore the norm for labour migration in both countries, and this let clandestine broker networks flourish. Due to the hidden nature of recruitment, travel, and positioning in the labour market in ways that were completely 'below the official radar', opportunities for exploitation were created in several ways and at several points in the migration process, and the implicit as well as explicit involvement of state actors in these systems was evident. The worst examples of extortion and exploitation came from migrants travelling to Libya, the Gulf States, and Singapore. The breakdown of the government in Libya and agreements with Europe to arrest and deport people trying to use North Africa to enter Europe through irregular routes have made migrants more vulnerable to exploitation and forced labour. Due to the constant threat of being arrested, irregular Ghanaian migrants in Libya remain invisible, and this provides employers with the power to underpay or not pay at all, using threats of reporting them to the authorities to extract more work. A comparable situation exists in Singapore and the Gulf States which heavily limits the rights of migrant labour.

Common to all scenarios was the prevalence of irregular migration and informal employment arrangements without official contracts. The combination of state migration control policies with insecure work and living conditions severely limits the ability of labour to bargain in the workplace and renders them vulnerable to deportation and criminalisation (Lewis et al. 2015, Strauss \& McGrath 2017). However, the accounts also show how migrants are using brokers to position themselves in the informal economy in order to resist being tied to the same employer for a particular kind of work and being returned home after a prescribed period of time. Stringent regulations 
related to work permits and quotas, as well as the duration of residence, mean that those who migrate through legal channels must work in the job that they have been assigned and remain with the same employer. Without the assistance of informal brokers, it is impossible to challenge the system. Migrants' accounts show that systems of brokerage can involve extreme risk and suffering as well as positioning of migrants in forced labour. But confounding this analysis are the findings that migrants continue to regard these avenues of migration as critical for entering the informal economy in destination countries where they have more flexibility in choosing jobs and switching employers. Brokers are important at every stage of migration - in applying for official documents if those are being sought, falsifying documents, negotiating passage with border authorities, arranging transport, and linking up with other brokers for onward journeys. They are also important for obtaining the necessary permits at the destination, renewal of passports and permits, as well as the system of stamping passports to allow migrants to extend their stay outside the legal system. Put differently, migrant agency relies heavily on brokers.

The ambivalence of migrant experiences shows that they are not wholly enslaved bodies, but nor are they able to exercise unconstrained agency. Their agency is always relational and the choices they make depend on their individual and family circumstances and their social and material context. It is these shades of grey in experiences that confound binary understandings of free and enslaved labour that we wish to highlight here. The findings presented in this paper have thus added to our understanding of the 'ambiguous realities of the lifeworlds' (Brace \& O'Connell Davidson 2018) in two hitherto under-researched contexts of the Global South.

The accounts provided by the migrants, brokers, state officials, and other stakeholders also show the conflicting role of the state. On the one hand, it positions itself as the only legitimate mediator of migration and a benevolent protector of migrant rights and safety, but it is clear that it also plays a critical role in facilitating irregular migration. States must therefore take more responsibility for their role in human trafficking and the creation of unfree labour.

\section{REFERENCES}

Alpes, M. J. (2013), 'Migration Brokerage, Illegality, and the State in Anglophone Cameroon', DIIS working paper 2013: 07, Danish Institute for International Studies (DIIS), Copenhagen. https://www.econstor.eu/handle/10419/122269

Anderson, B. \& O'Connell Davidson, J. (2003), 'Is Trafficking in Human Beings Demand Driven? A Multi-country Pilot Study', IOM Migration Research Series 15, International Organization for Migration.

https://www.compas.ox.ac.uk/wp-content/uploads/ER-2004-Trafficking_Demand_Driven_IOM.pdf; https://doi.org/10.18356/7891ac1c-en 
Awumbila, M., Deshingkar, P., Kandilige, L., Teye, J. K. \& Setrana, M. (2018), 'Please, Thank You and Sorry-Brokering Migration and Constructing Identities for Domestic Work in Ghana', Journal of Ethnic and Migration Studies. https://doi.org/10.1080/1369183X.2018.1528097

Ayalew, T., Adugna, F. \& Deshingkar, P. (2019), 'Social Embeddedness of Human Smuggling in East Africa: Brokering Ethiopian Migration to the Sudan', African Human Mobility Review, 4(3): 1333-58.

Baey, Grace \& Yeoh, Brenda S. A (2018), “ “The Lottery of My Life”: Migration Trajectories and the Production of Precarity among Bangladeshi Migrant Workers in Singapore's Construction Industry', Asian and Pacific Migration Journal, 27(3): 249-72. https://doi.org/10.1177/0117196818780087

Bailey, A. J. (2009), 'Population Geography: Lifecourse Matters', Progress in Human Geography, 33(3): 407-18. https://doi.org/10.1177/0309132508096355

Basok, T., Bélanger, D., Wiesner, M. L. R. \& Candiz, G. (2016), Rethinking Transit Migration: Precarity, Mobility, and Self-making in Mexico (London, Springer). https://doi.org/10.1057/9781137509758

Bastia, T. \& McGrath, S. (2011), 'Temporality, Migration and Unfree Labour: Migrant Garment Workers', Manchester Papers in Political Economy No. 6.

Bourdieu, P. (1997) La précarité est aujourd'hui partout: Intervention lors des Rencontres européennes contre la précarité (Paris, Raison d'Agir).

Brace, L. \& O’Connell Davidson, J. (eds) (2018), Revisiting Slavery and Antislavery: Towards a Critical Analysis (London, Palgrave Macmillan). https://doi.org/10.1007/978-3-319-90623-2

Buckley, M., McPhee, S. \& Rogaly, B. (2017), 'Labour Geographies on the Move: Migration, Migrant Status and Work in the 21st Century', Geoforum, 78: 153-8.

https://doi.org/10.1016/j.geoforum.2016.09.012

Carden, M. R. J. (2014), 'Smuggling of Female Migrant Workers from Myanmar to Thailand', Master of Arts thesis, Chulalongkorn University. https://cuir.car.chula.ac.th/dspace/bitstream/123456789/44685/1/5681215924.pdf

Carswell, G. \& De Neve, G. (2013), 'Labouring for Global Markets: Conceptualising Labour Agency in Global Production Networks', Geoforum, 44: 62-70.

https://doi.org/10.1016/j.geoforum.2012.06.008

Castles, S. (2002), 'Migration and Community Formation Under Conditions of Globalization', International Migration Review, 36(4): 1143-68. https://doi.org/10.1111/j.1747-7379.2002.tb00121.x

Coe, N. M. \& Jordhus-Lier, D. C. (2011) " Constrained Agency? Re-evaluating the Geographies of Labour', Progress in Human Geography, 35: 211-33. https://doi.org/10.1177/0309132510366746

Cranston, S., Schapendonk, J. \& Spaan, E. (2018), 'New Directions in Exploring the Migration Industries: Introduction to Special Issue', Journal of Ethnic and Migration Studies, 44(4): 543-57. https://doi.org/10.1080/1369183X.2017.1315504

De Genova, N. \& Peutz, N. (2010), The Deportation Regime: Sovereignty and the Freedom of Movement (Durham, NC, Duke University Press). https://doi.org/10.1215/9780822391340-002

Deleuze, G. \& Guattari F. (1987), A Thousand Plateaus: Capitalism and Schizophrenia (Minneapolis, MN, University of Minnesota Press).

della Porta, D., Hänninen, S., Siisiäinen, M. \& T. Silvasti, T. (2015), 'The Precarization Effect', in The New Social Division: Making and Unmaking Precariousness (London, Palgrave Macmillan), 1-23. https://doi.org/10.1057/9781137509352_1

Deshingkar, P. (2018), 'The Making and Unmaking of Precarious, Ideal Subjects-Migration Brokerage in the Global South. Introduction to the Special Issue', Journal of Ethnic and Migration Studies. https://doi.org/10.1080/1369183X.2018.1528094 
Deshingkar, P., Abrar, C. R., Sultana, M. T., Haque, K. N. H. \& Reza, M. S. (2018), 'Producing Ideal Bangladeshi Migrants for Precarious Construction Work in Qatar', Journal of Ethnic and Migration Studies. https://doi.org/10.1080/1369183X.2018.1528104

Deshingkar, P., Litchfield, J. \& Ting, W. (2019), 'Capitalizing Human Mobility for Poverty Alleviation and Inclusive Development in Myanmar (CHIME)', International Organization for Migration, Myanmar and University of Sussex.

Faist, T. (2014), 'Brokerage in Cross-border Mobility: Social Mechanisms and the (Re)production of Social Inequalities', Social Inclusion, 2(4): 38-52. https://doi.org/10.17645/si.v2i4.29

Fernandez, B. (2013), 'Traffickers, Brokers, Employment Agents, and Social Networks: The Regulation of Intermediaries in the Migration of Ethiopian Domestic Workers to the Middle East', International Migration Review, 47(4): 814-43. https://doi.org/10.1111/imre.12049

Frantz, E. (2013), 'Jordan's Unfree Workforce: State-sponsored Bonded Labour in the Arab Region', Journal of Development Studies, 49(8): 1072-87. https://doi.org/10.1080/00220388.2013.780042

Gallotti, M. \& Branch, I. L. M. (2015), 'Migrant Domestic Workers Across the World: Global and Regional Estimates', International Labour Organization Research Series.

https://www.ilo.org/wcmsp5/groups/public/---ed_protect/---protrav/---migrant/documents/briefingnote/wcms_490162.pdf

Gammeltoft-Hansen, T. \& Sorensen, N. N. (2013) The Migration Industry and the Commercialization of International Migration (London, Routledge).

Goh, C., Wee, K. \& Yeoh, B. S. (2016), 'Who's Holding the Bomb? Debt-financed Migration in Singapore's Domestic Work Industry', Working Paper 38, Migrating out of Poverty Research Programme Consortium.

https://assets.publishing.service.gov.uk/media/5992fd1040f0b679518fb4f0/WP38_Goh_et_ al_2016_Who_s_holding_the_bomb_Debt-financed_migration_in_Singapore_s_domestic_ work_industry.pdf

Goldring, L. \& Landolt, P. (2011), 'Caught in the Work-Citizenship Matrix: The Lasting Effects of Precarious Legal Status on Work for Toronto Immigrants', Globalizations, 8(3): 325-41. https://doi.org/10.1080/14747731.2011.576850

Guérin, I. (2013), 'Bonded Labour, Agrarian Changes and Capitalism: Emerging Patterns in South India', Journal of Agrarian Change, 13(3): 405-23. https://doi.org/10.1111/joac.12029

Hernandez-Leon, R. (2005), 'The Migration Industry in the Mexico-US Migratory System', Paper CCPR-049-05, California Center for Population Research On-Line Working Paper Series, University of California, Los Angeles.

https://www.diplomatie.gouv.fr/IMG/pdf/migrationindustry_mexico.pdf

Hopkins, P. \& Pain, R. (2007), 'Geographies of Age: Thinking Relationally', Area, 39(3): 287-94. https://doi.org/10.1111/j.1475-4762.2007.00750.x

Huang, S. \& Yeoh, B. S. (1998), 'Maids and Ma'ams in Singapore: Constructing Gender and Nationality in the Transnationalization of Paid Domestic Work', Geography Research Forum, 18: 22-48.

Johnson, M. (2018), 'From Victims of Trafficking to Freedom Fighters: Rethinking Migrant Domestic Workers in the Middle East', in L. Brace \& J. O'Connell Davidson (eds), Revisiting Slavery and Antislavery (London, Palgrave Macmillan), 179-205. https://doi.org/10.1007/978-3-319-90623-2_7

Katz, C. (2004) Growing Up Global: Economic Restructuring and Children's Everyday Lives (Minneapolis, MN, University of Minnesota Press).

Kobayashi, A. \& Preston, V. (2014), 'Being CBC: The Ambivalent Identities and Belonging of Canadianborn Children of Immigrants', Annals of the Association of American Geographers, 104(2): 234-42. https://doi.org/10.1080/00045608.2013.862133

Kusakabe, K. \& Pearson, R. (2010), 'Transborder Migration, Social Reproduction and Economic Development: A Case Study of Burmese Women Workers in Thailand', International Migration, 48(6): 13-43. https://doi.org/10.1111/j.1468-2435.2010.00630.x 
LeBaron, Genevieve \& Phillips, Nicola (2019), 'States and the Political Economy of Unfree Labour', New Political Economy, 24(1): 1-21. https://doi.org/10.1080/13563467.2017.1420642

Lerche, J. (2007), 'A Global Alliance Against Forced Labour? Unfree Labour, Neo-liberal Globalization and the International Labour Organization', Journal of Agrarian Change, 7(4): 42-52. https://doi.org/10.1111/j.1471-0366.2007.00152.x

Lewis, H., Dwyer, P., Hodkinson, S. \& Waite, L. (2015), 'Hyper-precarious lives: Migrants, Work and Forced Labour in the Global North', Progress in Human Geography, 39(5): 580-600. https://doi.org/10.1177/0309132514548303

Lindquist, J. (2012), 'The Elementary School Teacher, the Thug and his Grandmother: Informal Brokers and Transnational Migration from Indonesia', Pacific Affairs, 85(1): 69-89. https://doi.org/10.5509/201285169

Lindquist, J., Xiang, B. \& Yeoh, B. S. A. (2012), 'Opening the Black Box of Migration: Brokers, the Organization of Transnational Mobility and the Changing Political Economy in Asia', Pacific Affairs, 85(1): 7-19. https://doi.org/10.5509/20128517

Lucht, H. (2013), 'Pusher Stories: Ghanaian Connection Men and the Expansion of the EU's Border Regimes Into Africa', in The Migration Industry and the Commercialization of International Migration (London, Routledge), 191-207.

McCollum, D. \& Findlay, A. (2018), 'Oiling the Wheels? Flexible Labour Markets and the Migration Industry', Journal of Ethnic and Migration Studies, 44(4): 558-74. https://doi.org/10.1080/1369183X.2017.1315505

McKeown, A. (2012), 'How the Box Became Black: Brokers and the Creation of the Free Migrant', Pacific Affairs, 85(1): 21-45. https://doi.org/10.5509/201285121

Menjívar, C. \& Kanstroom, D. (eds), (2013), Constructing Immigrant 'Illegality': Critiques, Experiences, and Responses (Cambridge, Cambridge University Press).

O’Connell Davidson, J. (2013), 'Troubling Freedom: Migration, Debt, and Modern Slavery', Migration Studies, 1(2): 176-95. https://doi.org/10.1093/migration/mns002

Osella, F. (2014), 'The (Im)morality of Mediation and Patronage in South India and the Gulf', in A. Piliavsky (ed.), Patronage as Politics in South Asia (Delhi, Cambridge University Press), 365-94.

Osella, F. \& C. Osella, C. (2009), 'Muslim Entrepreneurs in Public Life Between India and the Gulf: Making Good and Doing Good', Journal of the Royal Anthropological Institute, 15: S202-21. https://doi.org/10.1111/j.1467-9655.2009.01550.x

Paret, Marcel \& Gleeson, Shannon (2016), 'Precarity and Agency through a Migration Lens', Citizenship Studies, 20(3-4): 277-94. https://doi.org/10.1080/13621025.2016.1158356

Parreñas, R. S. \& Silvey, R. (2016), 'Domestic Workers Refusing Neo-slavery in the UAE', Contexts, 15(3): 36-41. https://doi.org/10.1177/1536504216662235

Picherit, D. (2018), 'Labour Migration Brokerage and Dalit Politics in Andhra Pradesh: A Dalit Fabric of Labour Circulation', Journal of Ethnic and Migration Studies. https://doi.org/10.1080/1369183X.2018.1528101

Platt, M., Baey, G., Yeoh, B. S., Khoo, C. Y. \& Lam, T. (2017), 'Debt, Precarity and Gender: Male and Female Temporary Labour Migrants in Singapore', Journal of Ethnic and Migration Studies, 43(1): 119-36. https://doi.org/10.1080/1369183X.2016.1218756

Robertson, S. (2014), 'Time and Temporary Migration: The Case of Temporary Graduate Workers and Working Holiday Makers in Australia', Journal of Ethnic and Migration Studies, 40(12): 1915-33. https://doi.org/10.1080/1369183X.2013.876896

Rodriguez, R. M. \& Schwenken, H. (2013), 'Becoming a Migrant at Home: Subjectivation Processes in Migrant-sending Countries Prior to Departure', Population, Space and Place, 19(4): 375-88.

Rogaly, B. \& Thieme S. (2012), 'Experiencing Space-Time: The Stretched Lifeworlds of Migrant Workers in India', Environment and Planning A, 44(9): 2086-100. https://doi.org/10.1068/a44493 
Salt, J. \& Stein, J. (1997), 'Migration as a Business: The Case of Trafficking', International Migration, 35(4): 467-94. https://doi.org/10.1111/1468-2435.00023

Schapendonk, J. (2017), 'Navigating the Migration Industry: Migrants Moving through an AfricanEuropean Web of Facilitation/Control', Journal of Ethnic and Migration Studies, 44: 1-17. https://doi.org/10.1080/1369183X.2017.1315522

Sobieszczyk, T. (2002), 'Risky Business: Debt Bondage International Labour Migration from Northern Thailand', Ann Arbor, 1001: 48106-1248.

Standing, G. (2011), 'Workfare and the precariat', Soundings, 47(47): 35-43. https://doi.org/10.3898/136266211795427549

Strauss, K. (2017), 'Labour Geography 1: Towards a Geography of Precarity?', Progress in Human Geography, 42: 622-30. https://doi.org/10.1177/0309132517717786

Strauss, K. \& McGrath, S. (2017), 'Temporary Migration, Precarious Employment and Unfree Labour Relations: Exploring the 'Continuum of Exploitation in Canada's Temporary Foreign Worker Progra', Geoforum, 78: 199-208. https://doi.org/10.1016/j.geoforum.2016.01.008

Tyner, James A. (2004), Made in the Philippines: Gendered Discourses and the Making of Migrants (London, Routledge).

Van Liempt, I. (2007), Navigating Borders: Inside Perspectives on the Process of Human Smuggling into the Netherlands (Amsterdam, Amsterdam University Press). https://doi.org/10.5117/9789053569306

Van Liempt, I. \& Doomernik, J. (2006), 'Migrant's Agency in the Smuggling Process: The Perspectives of Smuggled Migrants in the Netherlands', International Migration, 44(4): 165-90.

Van Reisen, M. \& Rijken, C. (2015), 'Sinai trafficking: Origin and Definition of a New Form of Human Trafficking', Social Inclusion, 3(1): 113-24. https://doi.org/10.17645/si.v3i1.180

Ware, R. (2018), 'Libya: The Consequences of a Failed State', House of Commons briefing paper CBP 8314.

Webb, P. \& Garciandía, R. (2019), 'Are States Accountable for Modern Slavery?', 11 February, Blog of the Groningen Journal of International Law.

https://grojil.org/2019/02/11/are-states-accountable-for-modern-slavery/ [accessed on 11 May 2019].

Wee, K., Goh, C. \& Yeoh, B. S. A. (2018), 'Chutes-and-ladders: The Migration Industry, Conditionality, and the Production of Precarity among Migrant Domestic Workers in Singapore', Journal of Ethnic and Migration Studies. https://doi.org/10.1080/1369183X.2018.1528099

Xiang, B. \& Lindquist, J. (2014), 'Migration Infrastructure', International Migration Review, 48: S122-48. https://doi.org/10.1111/imre.12141

Zhang, Sheldon X., Sanchez, Gabriella E. \& Achilli, Luigi (2018), 'Crimes of Solidarity in Mobility: Alternative Views on Migrant Smuggling', The Annals of the American Academy of Political and Social Science, 676(1): 6-15. https://doi.org/10.1177/0002716217746908

\section{Notes on the authors}

Priya Deshingkar is Senior Research Fellow in Geography at the University of Sussex. Her research focusses on migration and poverty with a focus on precarity and agency, migration brokerage and the migration industry, debt-migration, human trafficking, and modern slavery.

p.deshingkar@sussex.ac.uk

\section{Recent publications:}

Deshingkar, P. (2018), 'The Making and Unmaking of Precarious, Ideal Subjects-Migration Brokerage in the Global South. Introduction to the Special Issue', Journal of Ethnic and Migration Studies. https://doi.org/10.1080/1369183X.2018.1528094 
Ayalew, T., Adugna, F. \& Deshingkar, P. (2019), 'Social Embeddedness of Human Smuggling in East Africa: Brokering Ethiopian Migration to the Sudan', African Human Mobility Review, 4(3): $1333-58$.

Deshingkar, P., Abrar, C. R., Sultana, M. T., Haque, K. N. H. \& Reza, M. S. (2018), 'Producing Ideal Bangladeshi Migrants for Precarious Construction Work in Qatar', Journal of Ethnic and Migration Studies. https://doi.org/10.1080/1369183X.2018.1528104

Mariama Awumbila is Professor of Geography at the University of Ghana. Her research interests are migration, livelihoods, and development; land and natural resource tenure and management; gender and development and poverty reduction strategies.

MAwumbila@ug.edu.gh

\section{Recent papers:}

Awumbila, M., Deshingkar, P., Kandilige, L., Teye, J. K. \& Setrana, M. (2018), 'Please, Thank You and Sorry-Brokering Migration and Constructing Identities for Domestic Work in Ghana', Journal of Ethnic and Migration Studies. https://doi.org/10.1080/1369183X.2018.1528097

Awumbila, M., Teye, J. K. \& Yaro, J. A. (2017), 'Social Networks, Migration Trajectories and Livelihood Strategies of Migrant Domestic and Construction Workers in Accra, Ghana', Journal of Asian and African Studies, 52(7): 982-96. https://doi.org/10.1177/0021909616634743

Awumbila, M., Teye, J. K., Litchfield, J., Boakye-Yiadom, L., Deshingkar, P. \& Quartey, P. (2015), 'Are Migrant Households Better Off Than Non-migrant Households? Evidence from Ghana', Migrating out of Poverty RPC Working Paper No. 28, Department for International Development, London.

https://www.gov.uk/dfid-research-outputs/are-migrant-households-better-off-than-non-migranthouseholds-evidence-from-ghana-migrating-out-of-poverty- rpc-working-paper-no-28

Joseph Kofi Teye is Professor of Geography and the Director of the Centre for Migration Studies, University of Ghana. His areas of specialisation are migration and development, environmental change and migration, agriculture commercialisation, and natural resource governance.

jteye@ug.edu.gh

\section{Recent publications:}

Yaro, J. A., Teye, J. K., \& Torvikey, G. D. (2017), 'Agricultural Commercialisation Models, Agrarian Dynamics and Local Development in Ghana', The Journal of Peasant Studies, 44(3): 538-54. https://doi.org/10.1080/03066150.2016.1259222

Teye, J. K., Alhassan, O. \& Setrana, M. B. (2017), 'Evolution and Nature of Diaspora Engagement Policies in Ghana', in J. Mangala (ed.), Africa and its Global Diaspora (London, Palgrave Macmillan), 143-73. https://doi.org/10.1007/978-3-319-50053-9_6

Teye, J. K., Awumbila, M. \& Darkwah, A. (2017), 'Gendered Dynamics of Remitting and Remittance Use in Northern Ghana', Working Paper 48, Migrating out of Poverty, University of Sussex. 
To cite the article: Priya Deshingkar, Mariama Awumbila and Joseph Kofi Teye (2019), 'Victims of trafficking and modern slavery or agents of change? Migrants, brokers, and the state in Ghana and Myanmar', Journal of the British Academy, 7(s1): 77-106.

DOI https://doi.org/10.5871/jba/007s1.077

This article is licensed under a

Creative Commons Attribution-NonCommercial-NoDerivs 4.0 Unported License.

Journal of the British Academy (ISSN 2052-7217) is published by

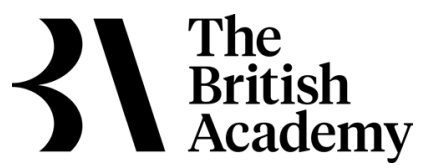

10-11 Carlton House Terrace, London, SW1Y 5AH

www.thebritishacademy.ac.uk 